\title{
Synthesis of Zr2Al3C4 coatings on zirconium-alloy substrates with Al-C/Si interlayers as diffusion barriers
}

J iamin Liang, Qiang Wei, Fangfang Ge, Donglou Ren, J i Wang, Yue Dong, Per Eklund, Feng Huang, Shiyu Du and Qing Huang

The self-archived postprint version of this journal article is available at Linköping University Institutional Repository (DiVA):

http:// urn.kb.se/ resolve?urn=urn:nbn:se:liu:diva- 154683

N.B.: When citing this work, cite the original publication.

Liang, J., Wei, Q., Ge, F., Ren, D., Wang, Ji, Dong, Y., Eklund, P., Huang, F., Du, S., Huang, Q., (2019), Synthesis of Zr2Al3C4 coatings on zirconium-alloy substrates with $\mathrm{Al}-\mathrm{C} / \mathrm{Si}$ interlayers as diffusion barriers, Vacuum, 160, 128-132. https:// doi.org/ 10.1016/j.vacuum.2018.11.029

Original publication available at:

https:// doi.org/ 10.1016/j.vacuum.2018.11.029

Copyright: Elsevier

http://www.elsevier.com/

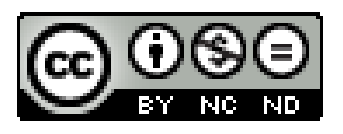




\section{Accepted Manuscript}

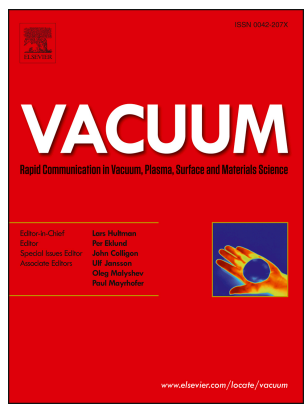

Synthesis of $\mathrm{Zr}_{2} \mathrm{Al}_{3} \mathrm{C}_{4}$ coatings on zirconium-alloy substrates with $\mathrm{Al}-\mathrm{C} / \mathrm{Si}$ interlayers as diffusion barriers

Jiamin Liang, Qiang Wei, Fangfang Ge, Donglou Ren, Ji Wang, Yue Dong, Per Eklund, Feng Huang, Shiyu Du, Qing Huang

PII: S0042-207X(18)31982-1

DOI: $\quad$ https://doi.org/10.1016/j.vacuum.2018.11.029

Reference: $\quad$ VAC 8385

To appear in: Vacuum

Received Date: 29 September 2018

Revised Date: 16 November 2018

Accepted Date: 16 November 2018

Please cite this article as: Liang J, Wei Q, Ge F, Ren D, Wang J, Dong Y, Eklund P, Huang F, Du S, Huang $Q$, Synthesis of $\mathrm{Zr}_{2} \mathrm{Al}_{3} \mathrm{C}_{4}$ coatings on zirconium-alloy substrates with $\mathrm{Al}-\mathrm{C} / \mathrm{Si}$ interlayers as diffusion barriers, Vacuum (2018), doi: https://doi.org/10.1016/j.vacuum.2018.11.029.

This is a PDF file of an unedited manuscript that has been accepted for publication. As a service to our customers we are providing this early version of the manuscript. The manuscript will undergo copyediting, typesetting, and review of the resulting proof before it is published in its final form. Please note that during the production process errors may be discovered which could affect the content, and all legal disclaimers that apply to the journal pertain. 
1

2

3 Jiamin Liang ${ }^{\mathrm{a}, \mathrm{b}}$, Qiang Wei ${ }^{\mathrm{a}, \mathrm{c}}$, Fangfang $\mathrm{Ge}^{\mathrm{b}}$, Donglou Ren ${ }^{\mathrm{b}}, \mathrm{Ji}_{\mathrm{W}} \mathrm{Wang}^{\mathrm{b}}$, Yue Dong ${ }^{\mathrm{b}}$, Per Eklund ${ }^{\mathrm{d}}$,

4 Feng Huang*b ${ }^{\mathrm{b}}$, Shiyu $\mathrm{Du}^{\mathrm{b}}$, Qing Huang** ${ }^{\mathrm{b}}$

5 a. Tianjin key Laboratory of Composite and Functional materials, School of Materials Science

6 and Engineering, Tianjin University, 300350 Tianjin, P. R. China.

7 b. Engineering Laboratory of Nuclear Energy Materials, Ningbo Institute of Materials Technology

\section{Synthesis of $\mathrm{Zr}_{2} \mathrm{Al}_{3} \mathrm{C}_{4}$ coatings on zirconium-alloy substrates with}

\section{Al-C/Si interlayers as diffusion barriers}

c. School of Mechanical Engineering, Hebei University of Technology, 300130 Tianjin, P. R. China

d. Thin Film Physics Division, Dept. of Physics, Chemistry, and Biology (IFM), Linköping University, SE-581 83, Linköping, Sweden

*Corresponding author: huangfeng @nimte.ac.cn

**Corresponding author: huangqing@nimte.ac.cn

\section{Abstract:}

$\mathrm{Zr}_{2} \mathrm{Al}_{3} \mathrm{C}_{4}$ coatings are potential candidates to prevent claddings of traditional Zr-based alloys from severe oxidation in water steam at high temperature. However, the diffusion of aluminum between coating and substrates at high temperature results in a coating composition deviating from the compositional domain for formation of the $\mathrm{Zr}_{2} \mathrm{Al}_{3} \mathrm{C}_{4}$ phase. Thus, synthesis of $\mathrm{Zr}_{2} \mathrm{Al}_{3} \mathrm{C}_{4}$ coatings on zirconium-alloy substrates is challenging. Here, we report that the $\mathrm{Zr}_{2} \mathrm{Al}_{3} \mathrm{C}_{4}$ phase can be obtained on zirconium alloy (ZIRLO) substrates where an $\mathrm{Al}-\mathrm{C} / \mathrm{Si}$ interlayer deposited by magnetron sputtering is introduced. The $\mathrm{Al}-\mathrm{C} / \mathrm{Si}$ interlayer prevented elemental diffusion of aluminum between the $\mathrm{Zr}-\mathrm{Al}-\mathrm{C}$ coating and the substrates during a 
26

27 32

post-annealing process at $800{ }^{\circ} \mathrm{C}$ for $3 \mathrm{~h}$. The $\mathrm{Al} / \mathrm{Zr}$ ratio of the $\mathrm{Zr}$-Al-C coating after annealing was $\sim 0.96$ and $\sim 0.59$ in the cases of with and without Al-C/Si interlayer, respectively. Hence, the $\mathrm{Al}-\mathrm{C} / \mathrm{Si}$ interlayer acts as diffusion barrier and greatly decreases the deviation from the standard stoichiometric ratio of the $\mathrm{Zr}_{2} \mathrm{Al}_{3} \mathrm{C}_{4}$ phase, which facilitates the formation of the $\mathrm{Zr}_{2} \mathrm{Al}_{3} \mathrm{C}_{4}$ phase in the final coating.

Key word: $\mathrm{Zr}_{2} \mathrm{Al}_{3} \mathrm{C}_{4}$, Coating, interlayer, Diffusion 


\section{Introduction}

It is important to enhance accident tolerance of traditional $\mathrm{Zr}$-based alloys for future high-safety reactors, because Zr-based alloys easily react with high-temperature steams. This reaction releases a large amount of hydrogen and can cause explosions, as in the Fukushima nuclear accident $[1,2]$. One strategy for the accident-tolerant fuels is to deposit ceramic coatings on the Zr-based alloys to improve the corrosion resistance of the Zr alloys, which doesn't adversely affect the nuclear material criteria $[3,4] . \mathrm{M}_{n+1} \mathrm{AX}_{n}$ (abbreviated as MAX, where $\mathrm{M}$ is an early transition metal, $\mathrm{A}$ is an IIIA- or IVA-group element, and $\mathrm{X}$ is $\mathrm{C}$ or $\mathrm{N}$ ) phase coatings are considered as potential protective coatings for the Zr-based alloy, due to their exceptional properties, combining the merits of metals and ceramics[5]. Among, $\mathrm{Zr}_{2} \mathrm{Al}_{3} \mathrm{C}_{4}$ that is a Zr-based and Al-rich MAX phase $\left(P 6_{3} / m m c\right.$ space group, $\left.a=b=3.34 \AA \mathrm{c}=22.2 \AA\right)[6$, 7], would be expected to have better compatibility with the $\mathrm{Zr}$ alloys and better oxidation resistance. He et al. investigated the oxidation behavior of $\mathrm{Zr}_{2} \mathrm{Al}_{3} \mathrm{C}_{4}$ bulk at $1600{ }^{\circ} \mathrm{C}$ and $1750{ }^{\circ} \mathrm{C}$, and found that the formed scales are intact and strongly bonded with the substrate below the eutectic temperature of $\mathrm{Al}_{2} \mathrm{O}_{3} / \mathrm{ZrO}_{2}$ [8]. Moreover, it was reported that $\mathrm{Zr}_{2} \mathrm{Al}_{3} \mathrm{C}_{4}$ ceramics exhibit good high-temperature mechanical properties. At $1400{ }^{\circ} \mathrm{C}$, the remaining strength of the $\mathrm{Zr}_{2} \mathrm{Al}_{3} \mathrm{C}_{4}$ ceramics is $287 \mathrm{MPa}$, which is about $77 \%$ of that at room temperature. [9].

However, less studies have been performed on the synthesis of $\mathrm{Zr}_{2} \mathrm{Al}_{3} \mathrm{C}_{4}$ coatings. Lai et al. deposited epitaxial $\mathrm{Zr}_{2} \mathrm{Al}_{3} \mathrm{C}_{4}$ films onto $\alpha-\mathrm{Al}_{2} \mathrm{O}_{3}(0001)$ and $4 \mathrm{H}-\mathrm{SiC}(001)$ substrates [10]. In contrast, it is much more difficult to deposit the $\mathrm{Zr}_{2} \mathrm{Al}_{3} \mathrm{C}_{4}$ coatings 
55

on the $\mathrm{Zr}$ alloys than that on the single crystal substrates. Firstly, the primary challenge is deviation from stoichiometry caused by the coating-substrate inter-diffusion at high temperatures. As indicated in the phase diagram of $\mathrm{Zr}-\mathrm{Al}-\mathrm{C}$ at $600{ }^{\circ} \mathrm{C}$, many $\mathrm{Zr}-\mathrm{Al}$ intermetallic compounds (e.g. $\mathrm{ZrAl}_{3}, \mathrm{ZrAl}_{2}, \mathrm{Zr}_{2} \mathrm{Al}_{3}, \mathrm{Zr}_{3} \mathrm{Al}$ ) exist in balance with the $\mathrm{Zr}_{2} \mathrm{Al}_{3} \mathrm{C}_{4}$ phase [11], which is thermodynamically stable in the triangular zone with end phases of $\mathrm{Zr}_{2} \mathrm{Al}_{3} \mathrm{C}_{5}, \mathrm{Zr}_{3} \mathrm{Al}_{3} \mathrm{C}_{5}$ and $\mathrm{ZrAl}_{3}$. A stoichiometric ratio (i.e., 2:3:4) of the three elements $(\mathrm{Zr}, \mathrm{Al}, \mathrm{C})$ is a prerequisite for the synthesis of the pure $\mathrm{Zr}_{2} \mathrm{Al}_{3} \mathrm{C}_{4}$ phase. Deviations from stoichiometry can result in impurity phases, and typically occurs during annealing at high temperature, due to significant inter-diffusion between the coating and substrate. Secondly, another concern is mismatches in the lattices and the thermal expansion coefficients between the $\mathrm{Zr}_{2} \mathrm{Al}_{3} \mathrm{C}_{4}$ coating and the substrates. The lattice mismatch $(\sim 3.37 \%)$ and their different thermal expansion coefficients $\left(8.1 \times 10^{-6} \mathrm{~K}^{-1}\right.$ for the $\mathrm{Zr}_{2} \mathrm{Al}_{3} \mathrm{C}_{4}$ and $7.2 \times 10^{-6} \mathrm{~K}^{-1}$ for the ZIRLO zirconium alloy) could affect the coating-substrate adhesion [10, 12]. We would prefer to use interlayers for reducing the mismatches between the $\mathrm{Zr}_{2} \mathrm{Al}_{3} \mathrm{C}_{4}$ coatings and the Zr-alloy substrates.

Here, we reported the synthesis of $\mathrm{Zr}_{2} \mathrm{Al}_{3} \mathrm{C}_{4}$ coatings on $\mathrm{Zr}$-alloy substrates (ZIRLO) by introducing a magnetron-sputter-deposited interlayer of $\mathrm{Al}-\mathrm{C} / \mathrm{Si}$ acting as diffusion barrier during post-annealing.

\section{Experimental details}

A Zr-Al-C coating with a Al-C/Si interlayer (i.e. Zr-Al-C/Al-C/Si) and a Zr-Al-C 
coating without any interlayers were deposited at room temperature (without ambient heating), by using a magnetron sputtering system (KYZK Development Co. Ltd, China), respectively. The plates of ZIRLO (State Nuclear Bao Ti Zirconium industry Co. Ltd, China) with the size of $15 \mathrm{~mm} \times 15 \mathrm{~mm} \times 1 \mathrm{~mm}$ were chosen as the substrates. The nominal composition (wt.\%) of ZIRLO is given as follows $\mathrm{Zr}$ bal; $\mathrm{Nb}, 1.10 ; \mathrm{Sn}, 1.10 ; \mathrm{Fe}, 0.11 ; \mathrm{O}, 0.13$. After being polished to 3000-grit and then polished to mirror with diamond polishing paste, the substrates were ultrasonically cleaned in acetone and ethanol each for $10 \mathrm{~min}$, blown dry in $\mathrm{N}_{2}$ gas, and immediately loaded into an ultrahigh-vacuum magnetron sputtering system. During the deposition process, four targets (diameter $100 \mathrm{~mm}$, thickness $4 \mathrm{~mm}, 99.99$ at. \% in purity, ZNXC Technology Co., Ltd) of $\mathrm{Zr}_{2} \mathrm{Al}$, Al, graphite, and Si were driven by the direct current (dc) powers; and the powers was $150 \mathrm{~W}, 42 \mathrm{~W}, 100 \mathrm{~W}$ and $450 \mathrm{~W}$, respectively. All the depositions were performed in Ar discharges at a pressure of $0.5 \mathrm{~Pa}$, with a substrate dc bias of $-15 \mathrm{~V}$. Before deposition, the chamber was evacuated to a pressure of approximate $2 \times 10^{-4} \mathrm{~Pa}$. The targets were pre-sputtered for at least $10 \mathrm{~min}$. Subsequently, the as-deposited samples were isothermally annealed at $800{ }^{\circ} \mathrm{C}$ for $3 \mathrm{~h}$ in vacuum, using a furnace (KYZK Development Co. Ltd, China). The $800{ }^{\circ} \mathrm{C}$ was selected for the annealing, because the $\mathrm{Zr}$ alloys generally proceed phase transition when the temperatures are more than $860{ }^{\circ} \mathrm{C}$. Prior to the annealing, the chamber was pumped down to $2.0 \times 10^{-3} \mathrm{~Pa}$. Both the heating and the cooling rates were fixed at $5{ }^{\circ} \mathrm{C} / \mathrm{min}$. Phase identification was performed by X-ray diffraction (XRD) on a Bruker D8 Advance diffractometer, and Raman spectroscopy on a LABRAM-HR system 
with the excitation laser of $532 \mathrm{~nm}$. Cross-sectional microstructures were examined by a field emission scanning electron microscope (SEM, FEI Quanta FEG 250) and transmission electron microscopy (TEM) on a FEI Tecnai F20 system operated at an acceleration voltage of $200 \mathrm{kV}$. An energy dispersive X-Ray spectroscopy (oxford instruments X-MAX 50) was used to determine the compositional profiles. The quantification was conducted using the XPP method and system build-in database. A focused ion beam (FIB) microscope (Auriga, Carl Zeiss) was used to prepare the cross-sectional TEM specimen. First, a rectangular region of $7 \mu \mathrm{m} \times 10 \mu \mathrm{m}$ was selected on the surface of the sample, and the Ga ion beams were used to bombard a rectangular region with the depth of $5 \mu \mathrm{m}$. Then the sides of the cross-section sample were thinned by the focused ion beam. The sample was thinned to about $500 \mathrm{~nm}$ at the voltage of $30 \mathrm{kV}$ and the current of $4 \mathrm{nA}-2 \mathrm{nA}$, and was further thinned from 500 $\mathrm{nm}$ to $100 \mathrm{~nm}$ at the voltage of $5 \mathrm{kV}$ and the current of $130 \mathrm{pA}-20 \mathrm{pA}$.

\section{Results and discussion}

Fig. 1 shows SEM images of the cross-section morphologies of the as-deposited coatings on the ZIRLO substrates, one for the Zr-Al-C coating without interlayer and another one with the Al-C/Si interlayer. The elemental compositions of the deposited $\mathrm{Zr}$-Al-C layers are identical in these two cases, with the atomic ratio of $\mathrm{Zr}$ : $\mathrm{Al}$ : $\mathrm{C}$ is 30.3: 47.3: 22.4. In Fig. 1a the coating only contains a dense and uniform Zr-Al-C layer with a thickness of $\sim 1.8 \mu \mathrm{m}$. There are three layers on the substrates in Fig. 1b, corresponding to an identical Zr-Al-C layer, a $150 \mathrm{~nm}$ thick Al-C interlayer, and a 200 
121

122

$\mathrm{nm}$ thick Si layer, respectively. The atomic ratio of $\mathrm{Al}$ : $\mathrm{C}$ is 37.7: 62.3 in the $\mathrm{Al}-\mathrm{C}$ interlayer.

XRD patterns and Raman spectra of the as-deposited coatings are presented in Fig. 2. The two as-deposited coatings exhibit similar XRD patterns and Raman spectra. Only the diffraction peaks of the ZIRLO substrates were detected. The characteristic peaks of the $\mathrm{Zr}_{2} \mathrm{Al}_{3} \mathrm{C}_{4}$ phase could be distinguished neither in the XRD patterns nor in the Raman spectra, which might suggest that the as-deposited coatings composed of amorphous phase, and the $\mathrm{Zr}_{2} \mathrm{Al}_{3} \mathrm{C}_{4}$ phase did not form at the room temperature.

After the $800{ }^{\circ} \mathrm{C}$ annealing, the $\mathrm{Zr}_{2} \mathrm{Al}_{3} \mathrm{C}_{4}$ phase did not appear in the interlayer-absent coating yet. In Fig. 2a, there is not any diffraction peaks of (002) plane for the $\mathrm{Zr}_{2} \mathrm{Al}_{3} \mathrm{C}_{4}$ MAX phase at $\sim 79^{\circ}$, maybe indicative of an absence of the $\mathrm{Zr}_{2} \mathrm{Al}_{3} \mathrm{C}_{4}$ phase, since the low-angle diffraction peaks are the characteristic peaks of the MAX phases $[13,14]$. The diffraction peaks in Fig. $2 \mathrm{a}$, such as $33.2^{\circ}, 37.5^{\circ}, 39.5^{\circ}$, 55.5, $60.5^{\circ}$, and $65.5^{\circ}$, might come from the $\mathrm{Zr}_{3} \mathrm{Al}_{3} \mathrm{C}_{5}$ or the $\mathrm{ZrAl}_{3}$. In the Raman spectrum (Fig. 2b), the Raman peaks at $\omega=178,544 \mathrm{~cm}^{-1}$ correspond the Raman active modes of $\mathrm{ZrC}$, and the peaks at $\omega=1335,1580 \mathrm{~cm}^{-1}$ are the so-called $\mathrm{D}$ and $\mathrm{G}$ bands of amorphous carbon [15]. But no distinct Raman peaks for the $\mathrm{Zr}_{2} \mathrm{Al}_{3} \mathrm{C}_{4}$ phase were detected. Based on the absences of the diffraction peak of (002) plane and the characteristic Raman peaks, we preferred to suggest that the $\mathrm{Zr}_{2} \mathrm{Al}_{3} \mathrm{C}_{4}$ phase might not form in the single-layer coating after the annealing.

However, the $\mathrm{Zr}_{2} \mathrm{Al}_{3} \mathrm{C}_{4}$ phase formed in the coating with the Al-C/Si interlayer 
143

144

145

after annealing at $800{ }^{\circ} \mathrm{C}$ for $3 \mathrm{~h}$, as demonstrated in the XRD pattern and the Raman spectrum of the annealed coating in Fig. 2c and Fig. 2d. Particularly, the typical diffraction peak at $7.9^{\circ}$ that originates from diffraction at the (002) planes of $\mathrm{Zr}_{2} \mathrm{Al}_{3} \mathrm{C}_{4}$ MAX phase [10, 16], was detected in the XRD pattern (Fig. 2c). The Raman peaks at $\omega=111,177,258,414$, and $625 \mathrm{~cm}^{-1}$ can also be assigned to the distinct Raman active-modes of $\mathrm{Zr}_{2} \mathrm{Al}_{3} \mathrm{C}_{4}$ [17]. Besides the $\mathrm{Zr}_{2} \mathrm{Al}_{3} \mathrm{C}_{4}$ phase, the $\mathrm{ZrAl}_{3}$ and the $\mathrm{Zr}_{3} \mathrm{Al}_{3} \mathrm{C}_{5}$ phases were also contained in the annealed coating. Their corresponding characteristic peaks appear in the XRD pattern, and the Raman peaks in Fig. 2d at $\omega=325,537,583 \mathrm{~cm}^{-1}$ could be attributed to the corresponding active modes of $\mathrm{Zr}_{3} \mathrm{Al}_{3} \mathrm{C}_{5}$ [18]. Moreover, the percentages of the phases, estimated from the strongest peaks of individual phase by the internal standard method, are $51.3 \%, 40.9 \%, 7.8 \%$ for the $\mathrm{Zr}_{2} \mathrm{Al}_{3} \mathrm{C}_{4}$, the $\mathrm{Zr}_{3} \mathrm{Al}_{3} \mathrm{C}_{5}$ and the $\mathrm{ZrAl}_{3}$, respectively. In the preparation process of bulk $\mathrm{Zr}_{2} \mathrm{Al}_{3} \mathrm{C}_{4}$, the $\mathrm{Zr}_{2} \mathrm{Al}_{3} \mathrm{C}_{4}$ and the $\mathrm{Zr}_{3} \mathrm{Al}_{3} \mathrm{C}_{5}$ phases simultaneously appeared above $1160{ }^{\circ} \mathrm{C}$, while the $\mathrm{ZrAl}_{3}$ phase dominates in lower temperature ranges [16]. According to the results of XRD and Raman, it could be concluded that the $\mathrm{Zr}_{2} \mathrm{Al}_{3} \mathrm{C}_{4}$ phase was obtained by annealing of the coating with the Al-C/Si interlayer, but did not form in the annealed single-layer $\mathrm{Zr}-\mathrm{Al}-\mathrm{C}$ coating

Fig. 3 shows cross-sectional TEM images of the annealed $\mathrm{Zr}-\mathrm{Al}-\mathrm{C} / \mathrm{Al}-\mathrm{C} / \mathrm{Si}$ coating. In a low-magnification image (Fig. 3a), three distinct layers are stacked in sequence, namely the $\mathrm{Zr}-\mathrm{Al}-\mathrm{C}$ layer, the interlayer, and the substrate. The interlayer is $\sim 100 \mathrm{~nm}$ in thickness, becoming thinner than that of the as-deposited one $(\sim 350 \mathrm{~nm})$, which could be attributable to composition homogenization due to the interdiffusion 
165

166

167

between the Zr-Al-C layer and the interlayer in the annealing process. In Fig. 3b, the selected-area electron diffraction pattern (SAED) that was taken from the $\mathrm{Zr}-\mathrm{Al}-\mathrm{C}$ layer, consists of rings mixed with several spots, indicative of random orientation. Consistently in a high-resolution TEM image (Fig. 3c), there are some nanosized grains, with the sizes of 5-10 $\mathrm{nm}$. Also apparent was that the grains with the large lattice distances $>5 \AA$ could be considered the $\mathrm{Zr}_{2} \mathrm{Al}_{3} \mathrm{C}_{4}$ phase, especially the lattice distance of $\sim 11.1 \AA$ that represents its (002) plane. Therefore, it could be confirmed that the nanosized $\mathrm{Zr}_{2} \mathrm{Al}_{3} \mathrm{C}_{4}$ crystal grains were contained in the $\mathrm{Zr}-\mathrm{Al}-\mathrm{C} / \mathrm{Al}-\mathrm{C} / \mathrm{Si}$ coating after the annealing treatment.

To better understand the mechanism of the formation of the $\mathrm{Zr}_{2} \mathrm{Al}_{3} \mathrm{C}_{4}$ phase in the $\mathrm{Zr}-\mathrm{Al}-\mathrm{C} / \mathrm{Al}-\mathrm{C} / \mathrm{Si}$ coating after the $800{ }^{\circ} \mathrm{C}$ annealing, we compared the cross-sectional SEM images and their corresponding EDS profiles between the single-layer coating and the coating with the Al-C/Si interlayer. In Fig. 4, overall the cross-sectional morphologies of the annealed coatings are different from those of the as-deposited ones (Fig. 1), maybe due to composition diffusion and phase formation occurred in the annealing processes. Fig. 4a shows that a compositional diffusion is predominant during the annealing process of the single-layer coating. The diffusion might be mainly considered as the $\mathrm{Al}$ atoms towards the $\mathrm{Zr}$ substrate, since the solubility limit of $\mathrm{Al}$ in $\mathrm{Zr}(1.2$ at.\%) is $\sim 17$ times as much as that of $\mathrm{Zr}$ in $\mathrm{Al}(0.07$ at.\%) at the 838-898 $\mathrm{K}$ temperature [19]. The $\mathrm{Al}$ atoms diffused towards the substrate, resulting into the formation of a $2-2.5 \mu \mathrm{m}$ thick Al-Zr mixed zone. The content of the $\mathrm{Zr}$ gradually decreases from the bottom of the coating to the surface. Such 
187

188

189

190

191

192

193

194

195

196

197

198

199

200

201

202

203

204

205

206

207

208

compositional diffusion was observed for $\mathrm{V}_{2} \mathrm{AlC}$ thin films [20]. However, the inter-diffusion of $\mathrm{Al}$ and $\mathrm{Zr}$ was impeded in the sample with $\mathrm{Al}-\mathrm{C} / \mathrm{Si}$ interlayer, as Fig. 4b shows. The $\mathrm{Zr}$ content in the coating is almost constant over the whole thickness and is substantially lower than that in the substrate, indicative of a relatively uniform distribution of the $\mathrm{Zr}$ composition in the coating. By contrast, the content of the $\mathrm{Al}$ composition is much higher in the coating than that in the $\mathrm{Zr}$ substrate; and the diffusion depth of the $\mathrm{Al}$ atoms into the substrate decreases to $1.5 \sim 2 \mu \mathrm{m}$. Instead, an aggregation zone of $\mathrm{Si}$ of $\sim 700 \mathrm{~nm}$ also formed in the surface/subsurface of the ZIRLO alloy substrate.

The chemical compositions of the as-deposited samples and the annealed samples are summarized in Table 1. The two as-deposited $\mathrm{Zr}$-Al-C layers have an $\mathrm{Al} / \mathrm{Zr}$ ratio of $\sim 1.56$. The $\mathrm{Al} / \mathrm{Zr}$ ratio decreases after the annealing treatment to $\sim 0.59$ and $\sim 0.96$ for the samples without and with the Al-C/Si interlayer, respectively. The compositions in Table 1 thus supports the interpretation that the inter-diffusion of the $\mathrm{Al}$ and the $\mathrm{Zr}$ atoms was reduced by the added Al-C/Si interlayer. Additionally, the Al-C sub-interlayer could partly compensate for the loss of Al during annealing, and reduce the deviation from the stoichiometric ratio of the $\mathrm{Zr}_{2} \mathrm{Al}_{3} \mathrm{C}_{4}$ phase.

According to the $\mathrm{Zr}-\mathrm{Al}-\mathrm{C}$ ternary phase diagram [11], the $\mathrm{Al} / \mathrm{Zr}$ ratio of $\sim 0.59$ is far from the stoichiometric ratio of the $\mathrm{Zr}_{2} \mathrm{Al}_{3} \mathrm{C}_{4}$ phase, and belongs to the three-phase region of $\mathrm{C}, \mathrm{ZrC}$ and $\mathrm{Zr}_{2} \mathrm{Al}_{3} \mathrm{C}_{5}$. Thus, it seemed reasonable that the $\mathrm{ZrC}$ and the amorphous carbon, instead of the $\mathrm{Zr}_{2} \mathrm{Al}_{3} \mathrm{C}_{4}$ phase, existed in the single-layer sample after the annealing. However, the $\mathrm{Al} / \mathrm{Zr}$ ratio of $\sim 0.96$ is in the three-phase region of 
209

210

211

212

213

214

215

$\mathrm{ZrAl}_{3}, \mathrm{Zr}_{2} \mathrm{Al}_{3} \mathrm{C}_{5}$ and $\mathrm{Zr}_{3} \mathrm{Al}_{3} \mathrm{C}_{5}$, being consistent with the observations that the three phases were present in the sample with the $\mathrm{Al}-\mathrm{C} / \mathrm{Si}$ interlayer. Based on the results above, we proposed that the $\mathrm{Al}-\mathrm{C} / \mathrm{Si}$ interlayer can reduce the deviation from the stoichiometry of the $\mathrm{Zr}$-Al-C ternary phase that usually occurs in the coatings on $\mathrm{Zr}$-alloy substrates at high-temperature. Finally, it is worth to point out two main problems in this work. The annealing temperature and the annealing time are required to be further lower, otherwise the $\mathrm{Zr}$ substrates will be damaged at the high temperature annealing for the long time. Moreover, the coatings were not suitable in practice application yet, as the low purity ( 51.3\%) of the $\mathrm{Zr}_{2} \mathrm{Al}_{3} \mathrm{C}_{4}$ MAX phase and the random orientations could result into swelling and cracking of the coatings upon neutron irradiation. Therefore, in the future work, we plan to optimize the Al-C/Si interlayer or design other interlayers, such as $\mathrm{Al}_{2} \mathrm{O}_{3}$. In addition, we are also going to use our one-step synthesis, by which we have obtained phase-pure $\mathrm{V}_{2} \mathrm{AlC}$ MAX phase films at $600{ }^{\circ} \mathrm{C}$ on amorphous substrates [21].

\section{Conclusions}

$\mathrm{Zr}_{2} \mathrm{Al}_{3} \mathrm{C}_{4}$ phase on ZIRLO substrates can be obtained in magnetron sputtered $\mathrm{Zr}-\mathrm{Al}-\mathrm{C}$ coatings by adding an $\mathrm{Al}-\mathrm{C} / \mathrm{Si}$ interlayer between the $\mathrm{Zr}-\mathrm{Al}-\mathrm{C}$ layer and the substrate, followed by annealing at $800{ }^{\circ} \mathrm{C}$ for $3 \mathrm{~h}$. The Al-C/Si interlayer can impede inter-diffusion of the $\mathrm{Al}$ and the $\mathrm{Zr}$ atoms, and retain the element composition close to the stoichiometry of $\mathrm{Zr}_{2} \mathrm{Al}_{3} \mathrm{C}_{4}$ phase, which helps the formation of $\mathrm{Zr}_{2} \mathrm{Al}_{3} \mathrm{C}_{4}$ phase. 
231

232

233

234

235

236

237

238

239

240

241

242

243

244

245

246

247

248

249

250

251

252

253

\section{Acknowledgements:}

The present work was supported by the National Natural Science Foundation of China (Grant No. 91226202, 91426304 and 51873146), and the Major Project of the

Ministry of Science and Technology of China (Grant No.2015 ZX06004-001). P. E. acknowledges the Knut and Alice Wallenberg Foundation trough the Wallenberg Academy Fellows program and the Swedish Government Strategic Research Area in Materials Science on Functional Materials at Linköping University (Faculty Grant SFO-Mat-LiU No. 2009 00971).

\section{References}

[1] H.G. Kim, J.H. Yang, W.J. Kim, Y.H. Koo, Development Status of Accident-tolerant Fuel for Light Water Reactors in Korea, Nuclear Engineering \& Technology 48(1) (2016) 1-15.

[2] D.J. Park, H.G. Kim, Y.I. Jung, J.H. Park, J.H. Yang, Y.H. Koo, Behavior of an improved Zr fuel cladding with oxidation resistant coating under loss-of-coolant accident conditions, Journal of Nuclear Materials 482 (2016) 75-82.

[3] M. Kurata, Research and Development Methodology for Practical Use of Accident Tolerant Fuel in Light Water Reactors, Nuclear Engineering and Technology 48(1) (2016) 26-32.

[4] C.M. Lee, D.S. Sohn, Enhanced high-temperature oxidation resistance of a zirconium alloy cladding by high-temperature preformed oxide on the cladding, Corrosion Science 131 (2018) 116-125.

[5] P. Eklund, M. Beckers, U. Jansson, H. Högberg, L. Hultman, The $M_{n+1} A X_{n}$ phases: Materials science and thin-film processing, Thin Solid Films 518(8) (2010) 1851-1878. 
[6] J.Y. Wang, Y.C. Zhou, Recent Progress in Theoretical Prediction, Preparation, and Characterization of Layered Ternary Transition-Metal Carbides, Annual Review of Materials Research 39(1) (2009) 415-443.

[7] Y.C. Zhou, L.F. He, Z.J. Lin, J.Y. Wang, Synthesis and structure-property relationships of a new family of layered carbides in $\mathrm{Zr}-\mathrm{Al}(\mathrm{Si})-\mathrm{C}$ and $\mathrm{Hf}-\mathrm{Al}(\mathrm{Si})-\mathrm{C}$ systems, Journal of the European Ceramic Society 33(15-16) (2013) 2831-2865.

[8] L.F. He, H.B. Zhong, J.J. Xu, M.S. Li, Y.W. Bao, J.Y. Wang, Y.C. Zhou, Ultrahigh-temperature oxidation of $\mathrm{Zr}_{2} \mathrm{Al}_{3} \mathrm{C}_{4}$ via rapid induction heating, Scripta Materialia 60(7) (2009) 547-550.

[9] L.F. He, X.P. Lu, Y.W. Bao, J.Y. Wang, Y.C. Zhou, High-temperature internal friction, stiffness and strength of $\mathrm{Zr}-\mathrm{Al}(\mathrm{Si})-\mathrm{C}$ ceramics, Scripta Materialia 61(1) (2009) 60-63.

[10] C-C. Lai, M.D. Tucker, J. Lu, J. Jensen, G. Greczynski, P. Eklund, J. Rosen, Synthesis and characterization of $\mathrm{Zr}_{2} \mathrm{Al}_{3} \mathrm{C}_{4}$ thin films, Thin Solid Films 595 (2015) 142-147.

[11] J.C. Schuster, H. Nowotny, Investigations of the Ternary Systems ( $\mathrm{Zr}, \mathrm{H}, \mathrm{Nb}, \mathrm{Ta})-\mathrm{Al}-\mathrm{C}$ and Studies on Complex Carbides, Zeitschrift fuer Metallkunde/Materials Research and Advanced Techniques 71 (1980) 341-346.

[12] V. Petukhov, Thermal expansion of zirconium in the solid phase, High Temperatures-High Pressures 35-6 (2003) 15-23.

[13] J.J. Li, L.F. Hu, F.Z. Li, M.S. Li, Y.C. Zhou, Variation of microstructure and composition of the $\mathrm{Cr}_{2} \mathrm{AlC}$ coating prepared by sputtering at 370 and $500^{\circ} \mathrm{C}$, Surface and Coatings Technology 204 (2010) 3838-3845.

[14] Q.M. Wang, W. Garkas, A.F. Renteria, C. Leyens, H.W. Lee, K.H. Kim, Oxidation behaviour of Ti-Al-C films composed mainly of a $\mathrm{Ti}_{2} \mathrm{AlC}$ phase, Corrosion Science 53 (2011) 2948-2955.

[15] C. Tang, M. Klimenkov, U. Jaentsch, H. Leiste, M. Rinke, S. Ulrich, M. Steinbrück, H.J. Seifert, M. Stueber, Synthesis and characterization of $\mathrm{Ti}_{2} \mathrm{AlC}$ coatings by magnetron sputtering from three elemental targets and ex-situ annealing, Surface and Coatings Technology 309 (2017) 445-455.

[16] L.F. He, Z.J. Lin, J.Y. Wang, Y.W. Bao, M.S. Li, Y.C Zhou, Synthesis and Characterization of Bulk $\mathrm{Zr}_{2} \mathrm{Al}_{3} \mathrm{C}_{4}$ Ceramic, Journal of the American Ceramic Society 90 (2007) 3687-3689. 
284 [17] L. Wu, L.F. He, Y.W. Bao, Y.C. Zhou, Tribological Properties of a $\mathrm{Zr}_{2} \mathrm{Al}_{3} \mathrm{C}_{4}$ Ceramic at

285

286

287

288

289

290

291

292

293

294

295

296

297

298

299

300

301

302

303

304

305

306

307 Ambient Temperature, Journal of the American Ceramic Society 92(1) (2009) 141-146.

[18] J. Zhou, X.H. Zha, F.Y. Chen, Q. Ye, P. Eklund, S.Y. Du, Q. Huang, A Two-Dimensional Zirconium Carbide by Selective Etching of $\mathrm{Al}_{3} \mathrm{C}_{3}$ from Nanolaminated $\mathrm{Zr}_{3} \mathrm{Al}_{3} \mathrm{C}_{5}$, Angewandte Chemie 55(16) (2016) 5008-13.

[19] A. Laik, K. Bhanumurthy, G.B. Kale, Intermetallics in the $\mathrm{Zr}-\mathrm{Al}$ diffusion zone, Intermetallics 12(1) (2004) 69-74.

[20] Z. Wang, X. Li, J. Zhou, P. Liu, Q. Huang, P. Ke, A. Wang, Microstructure evolution of V$\mathrm{Al}-\mathrm{C}$ coatings synthesized from a $\mathrm{V}_{2} \mathrm{AlC}$ compound target after vacuum annealing treatment, Journal of Alloys and Compounds 661 (2016) 476-482.

[21] R. Shu, F.F. Ge, F.P. Meng, P. Li, J. Wang, Q. Huang, P. Eklund, F. Huang, One-step synthesis of polycrystalline $\mathrm{V}_{2} \mathrm{AlC}$ thin films on amorphous substrates by magnetron co-sputtering, Vacuum 146 (2017) 106-110. 
309 Fig. 1. Cross-sectional morphology of the as-deposited Zr-Al-C coatings on the ZIRLO alloy

310 substrates (a) without interlayers, and (b) with a Al-C/Si interlayer.

311 Fig. 2. XRD patterns and Raman spectra of the as-deposited and annealed samples. (a) and (b) for the sample without interlayer. (c) and (d) for the sample with the Al-C/Si interlayer. The

313 background of the XRD patterns was removed. The range of peak positions taken from JCPDF 314 card \#78-1801, \#65-5706, \#70-2655 and \#05-0665.

315 Fig. 3. TEM cross-section images of the annealed $\mathrm{Zr}-\mathrm{Al}-\mathrm{C} / \mathrm{Al}-\mathrm{C} / \mathrm{Si}$ coating on the ZIRLO 316 substrate. (a) An overview image, (b) a selective area electron diffraction (SAED) patterns marked in (a), (c) a HRTEM image showing individual grains outlined by dashed lines

Fig. 4. Cross-sectional SEM images and their corresponding EDS linescans for the annealed samples, (a) the $\mathrm{Zr}-\mathrm{Al}-\mathrm{C}$ coating without interlayer, (b) the coating with the Al-C/Si interlayer 
Table 1 Chemical compositions of the as-deposited and the annealed samples by EDS (at \%)

\begin{tabular}{cccc}
\hline \multirow{2}{*}{ Element } & As-deposited & \multicolumn{2}{c}{ Annealed Zr-Al-C coating } \\
\cline { 3 - 4 } & Zr-Al-C & Without interlayer & With interlayer \\
\hline $\mathrm{Zr}$ & 30.3 & 28.3 & 27.6 \\
\hline $\mathrm{Al}$ & 47.3 & 16.8 & 26.6 \\
\hline $\mathrm{Al} / \mathrm{Zr}$ & 1.56 & 0.59 & 0.96 \\
\hline
\end{tabular}




\section{ACCEPTED MANUSCRIPT}

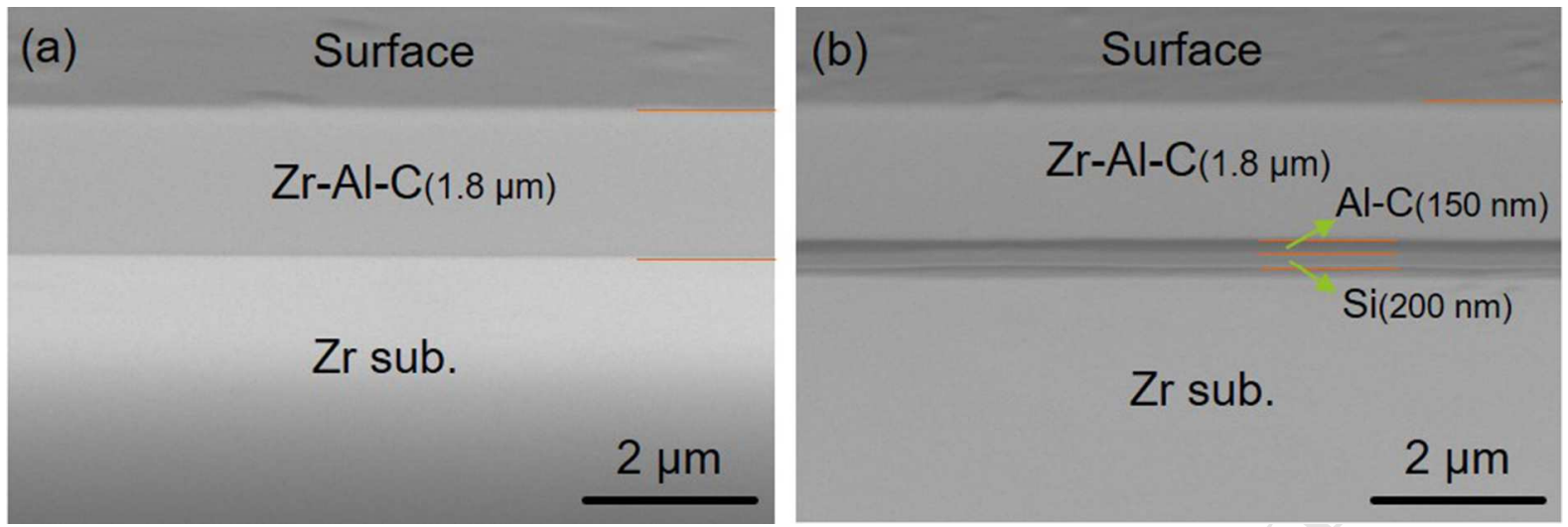



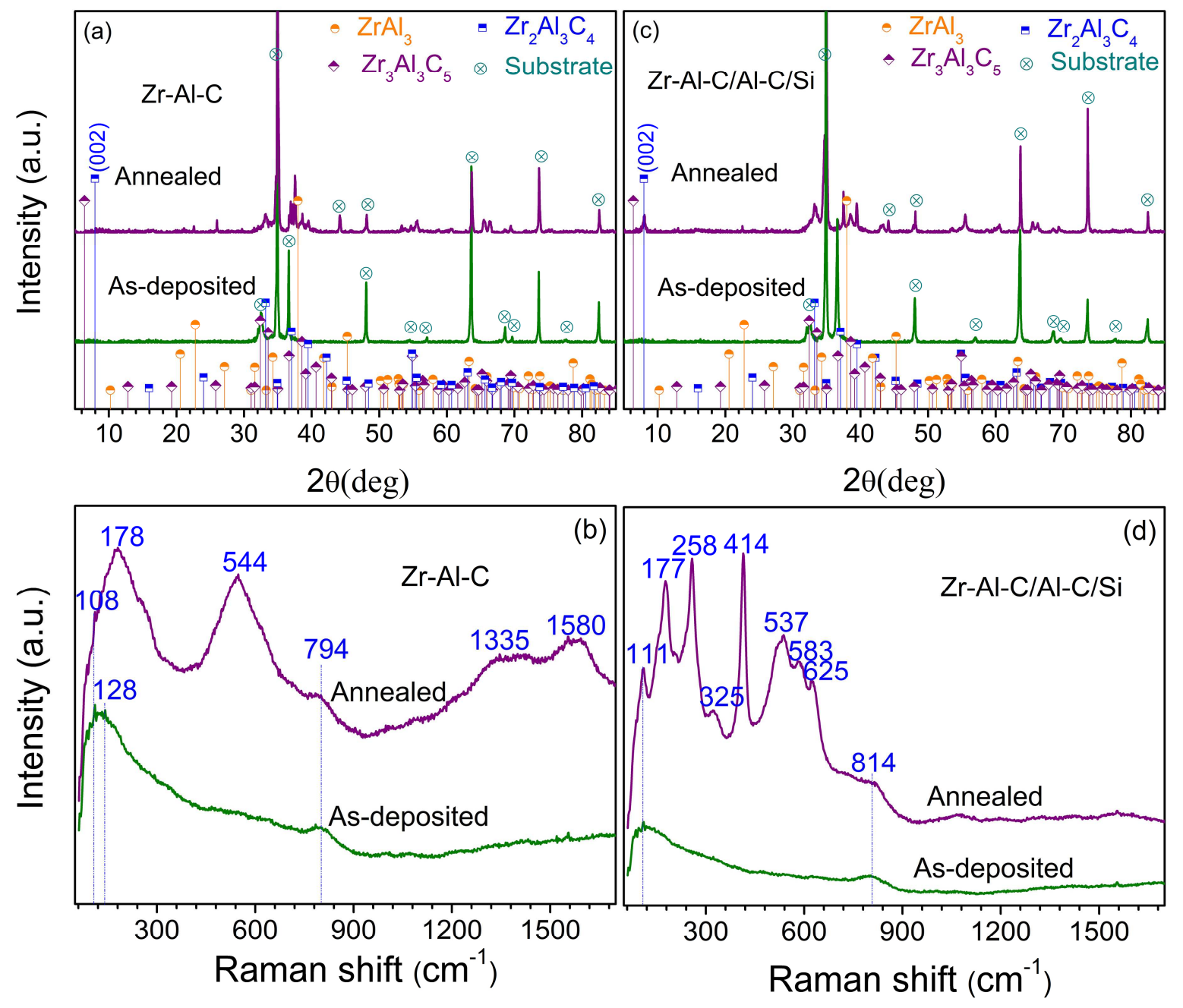


\section{ACCEPTED MANUSCRIPT}

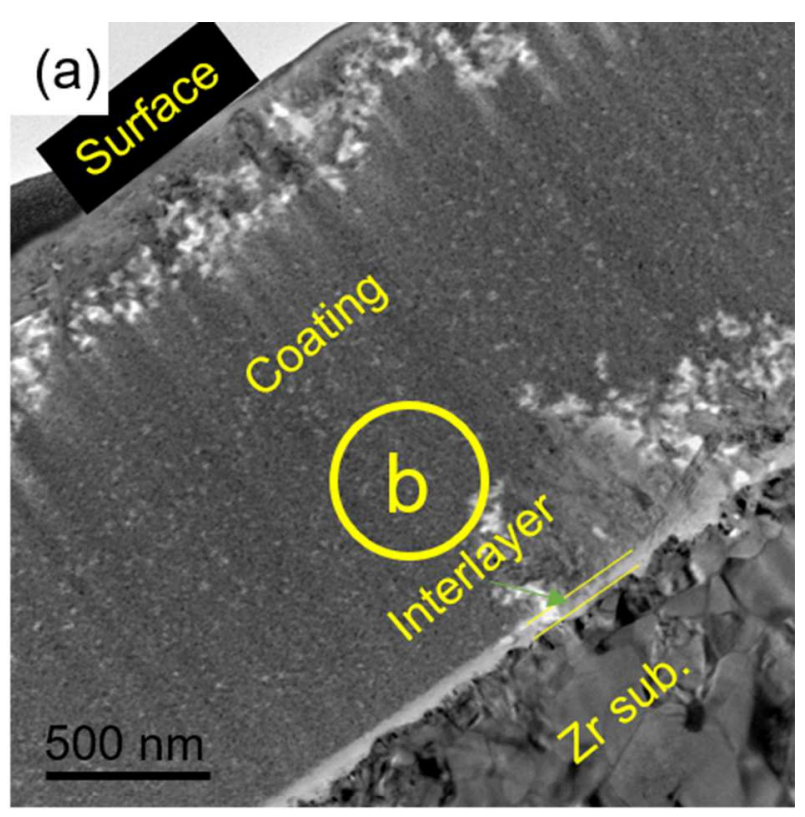

(b)

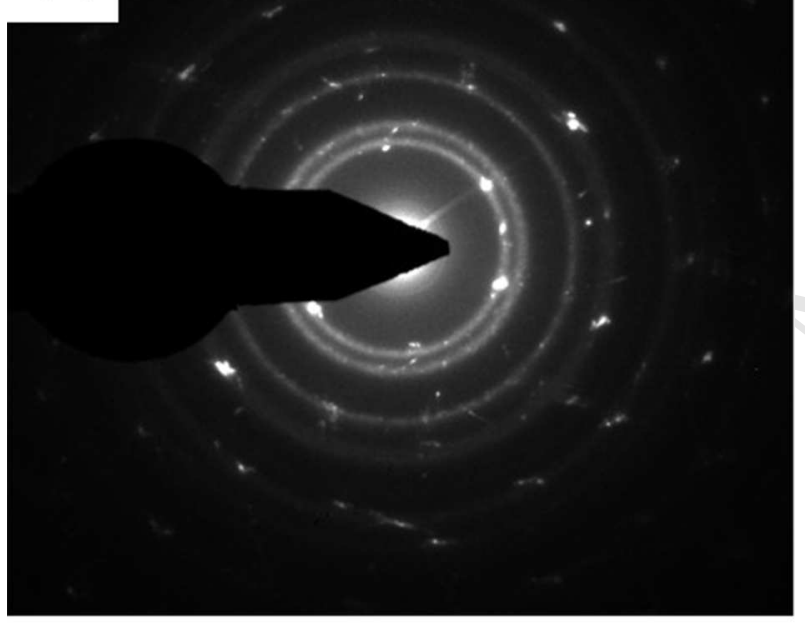

(c)

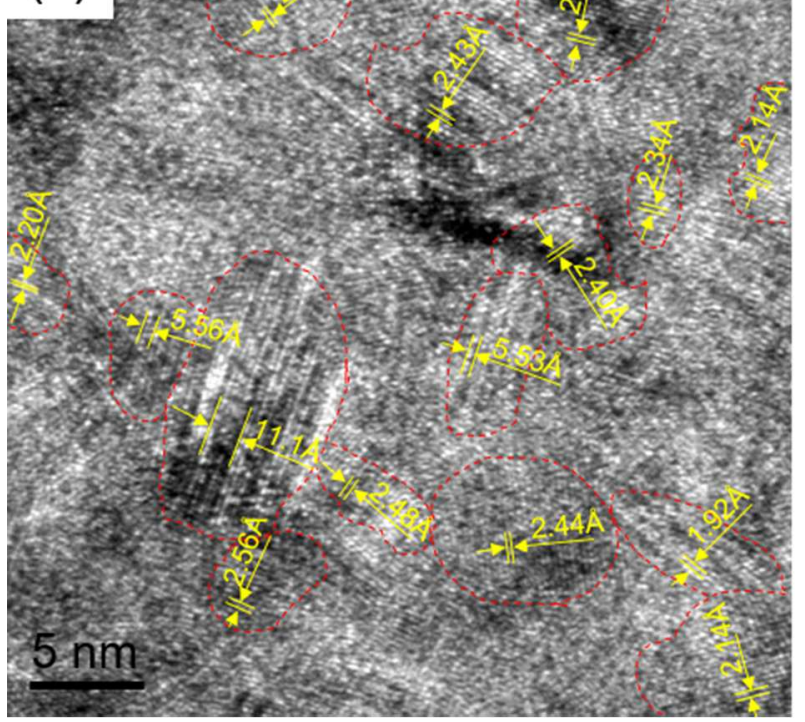




\section{ACCEPTED MANUSCRIPT}
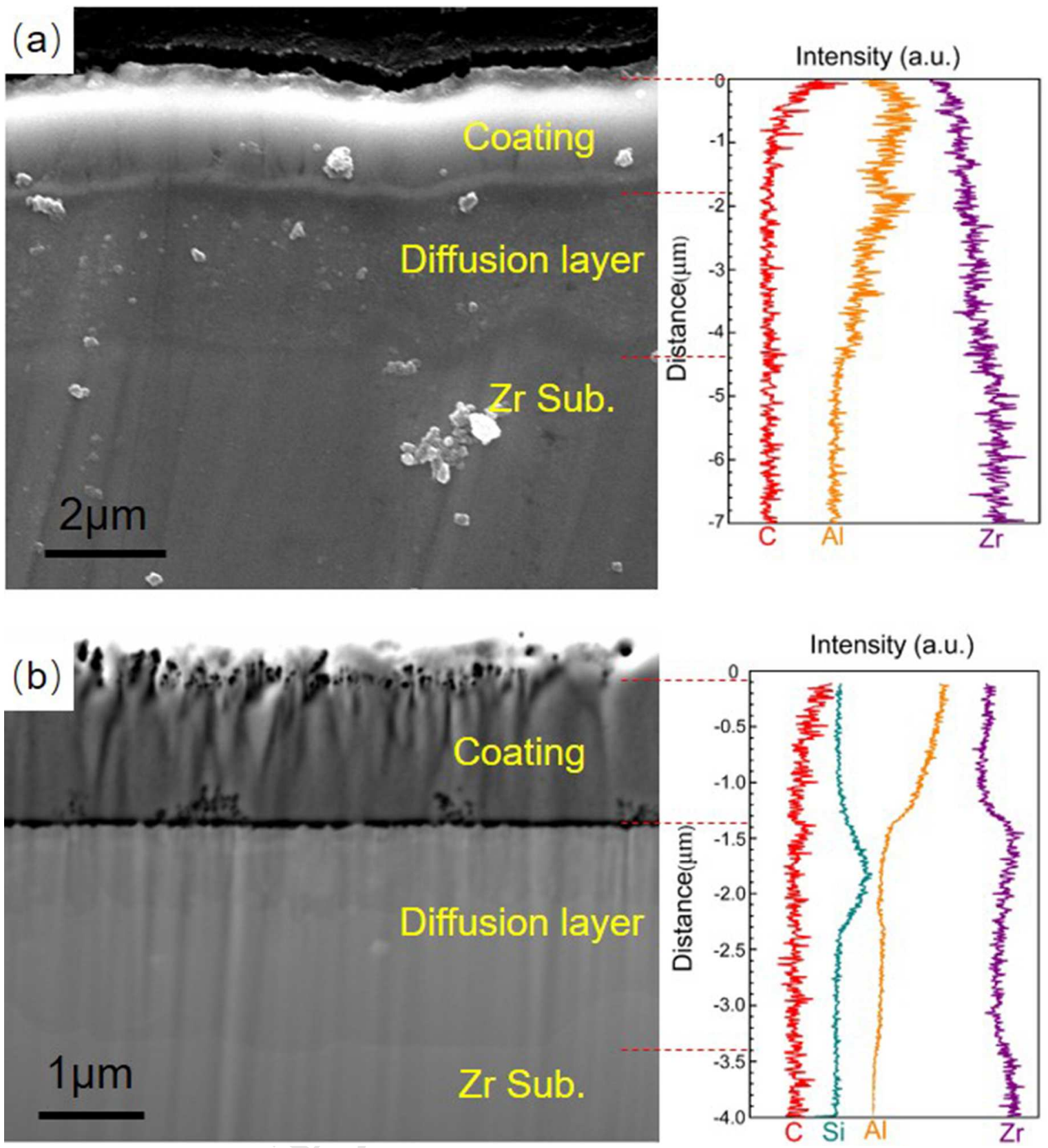
Highlight

1 , the interlayer barrier is crucial to inhibit the inter-diffusion of elements between $\mathrm{Zr}$ substrate and $\mathrm{Zr}_{2} \mathrm{Al}_{3} \mathrm{C}_{4}$ coating;

2, $\mathrm{Zr}_{2} \mathrm{Al}_{3} \mathrm{C}_{4}$ coatings are successfully synthesized on zirconium-alloy that will be a promising candidates as accident tolerant fuel cladding. 